\title{
ENVISIONING INNOVATIVE GROUNDWATER REGULATION POLICIES THROUGH SCENARIO WORKSHOPS IN FRANCE AND PORTUGAL ${ }^{\dagger}$
}

\author{
J-D RINAUDO ${ }^{1 *}$, M. MONTGINOUL $^{2}$, M. VARANDA ${ }^{3}$ AND S. BENTO ${ }^{4}$ \\ ${ }^{1}$ BRGM (French Geological Survey) Water Department, Montpellier, France \\ ${ }^{2} U M R$ G-EAU, IRSTEA-Cemagref, Montpellier, France \\ ${ }^{3}$ ICS, University of Lisbon, Lisbon, Portugal \\ ${ }^{4}$ ISEG/Universidade Técnica de Lisboa (SOCIUS), Lisbon, Portugal
}

\begin{abstract}
Groundwater management policies will need to be revised in many Mediterranean countries, in light of the impact of climate change and the increasing demand for water. In this paper, we analyse stakeholder perceptions of three groundwater policy scenarios which respectively assume a strengthening of state intervention, the introduction of market regulation mechanisms, and the transfer of regulation responsibility to farmers. The method consists of organizing scenario workshops with experts, institutional representatives and farmers. It is applied in two case studies in France and Portugal. From a methodological viewpoint, the research demonstrates farmers' ability to contribute to an exploratory assessment of possible future water management scenarios. From a policy viewpoint, it clarifies expectations concerning state intervention and self-regulation by farmers. It also provides some insights regarding the acceptability of tradable groundwater permits in two European contexts. Copyright (C) 2012 John Wiley \& Sons, Ltd.
\end{abstract}

KEY WORDS: climate change; groundwater management; water markets; self-regulation; France; Portugal; scenario workshops

\section{RÉSUMÉ}

Les politiques de gestion des eaux souterraines devront être adaptées pour faire face aux enjeux du changement climatique et à l'augmentation de la demande en eau d'irrigation. Dans cet article, nous analysons la perception par les acteurs de l'eau de trois scénarios prospectifs de gestion des eaux souterraines, qui supposent respectivement un renforcement de l'intervention de l'Etat, l'introduction de mécanismes de marchés ou le transfert de la régulation des prélèvements aux agriculteurs. La méthode consiste à organiser des ateliers de prospective avec des experts, des représentants institutionnels et des agriculteurs. Elle est mise en oeuvre dans deux cas d'étude en France et au Portugal. D'un point de vue méthodologique, la recherche démontre que les agriculteurs peuvent apporter une contribution substantielle à une évaluation prospective de mécanismes alternatifs de gestion des ressources en eau. Du point de vue de la politique de l'eau, l'article met en évidence les attente des acteurs concernant l'intervention de l'Etat et le transfert de responsabilité aux usagers. Il éclaire également les problèmes d'acceptabilité, dans le contexte européen, des systèmes de permis négociables envisagès pour assurer l'allocation de la ressource en eau souterraine. Copyright () 2012 John Wiley \& Sons, Ltd.

MOTS CLÉS: changement climatique; gestion eaux souterraines; marchés de l'eau; gestion communautaire; France; Portugal; prospective participative

\section{INTRODUCTION}

Over the last several decades, groundwater abstraction has increased considerably in northern Mediterranean countries (European Academies Science Advisory Council (EASAC), 2010) and even more in southern Mediterranean countries.

\footnotetext{
* Correspondence to: J-D. Rinaudo, BRGM, 1034 rue de Pinville, 34000 Montpellier, France. Tel.: +33 467791 585. E-mail: jd.rinaudo@brgm.fr

${ }^{\dagger}$ Vers de nouvelles politiques de regulation des eaux souterraines? Résultats d'une prospective exploratoire.
}

Government agencies have not paid much attention to this 'silent revolution' (Llamas and Garrido, 2007), and groundwater development has thus taken place in an institutional setting that placed no or few limits on groundwater use (Schlager, 2007). As a result, it is only after several decades, and investments made by thousands of farmers, that the consequences of these overdrafts, e.g. seawater intrusion, have started to appear, conflicts are escalating, and that establishing new rules for governing access to groundwater is seen as an absolute necessity. 
In France and Portugal, the two countries considered in this paper, controlling groundwater abstraction is becoming a significant water policy issue. To comply with the requirements of the European Union Water Framework Directive, water authorities now have to develop a programme of actions leading to the 'good quantitative status' of all groundwater bodies. One of the first actions implemented has consisted of estimating the maximum inter-annual average volume that can be pumped from a number of critical groundwater basins characterized by a risk of overexploitation. In parallel, specific efforts are made to complete the registration of all existing boreholes, including illegal ones. The next step for groundwater policy development will consist of developing and implementing new rules for sharing a limited quantity of water among economic sectors, and between users within each sector. Long-term climate change prospects will need to be considered while crafting such new rules for governing groundwater allocation, as they will probably have to be enforced in a context of increased water scarcity (García-Ruiz et al., 2011).

For agricultural water users and their institutional representatives, the development and implementation of rules regulating access to and use of groundwater will be perceived as a paradigm shift, since most of them still consider groundwater to be an open-access good. To enhance the adequacy of regulations, as regards equity but also acceptability, and to reduce future implementation and enforcement problems, stakeholders and users should be involved in the development of such regulations (Ostrom, 1990). Their participation is essential because the policy options considered represent drastic changes that will call into question established institutions, societal values, and dominant ideologies and beliefs. Moreover, the practical (lay) knowledge of the stakeholders is essential for crafting rules that can work effectively in the context of local, technical, environmental, institutional, socioeconomic and, more generally, cultural constraints (Rinaudo and Garin, 2005). There are very few 'off-the-shelf' groundwater regulation models that could be imported from other countries without significant adaptation to the local context. This adaptation may require a lot of creativity which is likely to be enhanced by the confrontation of multiple visions of existing constraints and possible futures.

This paper aims to contribute to the scientific literature which explores how to craft rules for regulating groundwater usage. It is based on two concrete case studies conducted in France and Portugal, where a similar methodology was used. This consisted of organizing workshops with a group of institutional stakeholders, i.e. local administration representatives, economic actors, non-governmental organization (NGO) staff, and scientific experts, and several groups of farmers, during which three contrasting groundwater regulation scenarios were scrutinized and debated. The paper describes both the visions that emerged from the workshops and the social learning process that took place during them.

The remainder of this paper is organized as follows. The next section presents the participatory foresight methodology used in this study, and the two case studies-France and Portugal-where it was applied. The second section describes the three groundwater regulation policy scenarios which were constructed and debated in the workshops by the French and Portuguese farmers and institutional stakeholders. The third section shows how these scenarios were perceived by the workshops' participants, and the lessons learnt for policy making. The last section evaluates the methodology and provides some policy recommendations.

\section{METHODOLOGY AND CASE STUDIES}

\section{Unfolding the future in three steps}

The common methodology implemented in the French and Portuguese case studies was inspired by the emerging literature on scenario planning and participatory foresight for water resources management (see e.g. van der Helm, 2003; Hatzilacou et al., 2007). Foresight is defined here as a multidisciplinary approach whose goal is to help decision-makers explore the uncertainty associated with future developments, and to assess the consequences of the various strategic choices available. The approach here consisted of exploring a limited number of scenarios, each of which describes a possible future institutional set-up for groundwater regulation. The aim here is 'to illuminate the choices of the present in the light of possible futures' (Godet and Roubelat, 1996), rather than to make predictions.

A group of institutional stakeholders and several groups of farmers were invited to participate in three series of workshops. In order to enhance the envisioning capacity of the participants, we adopted a sequential approach to future exploration. The first sequence was devoted to the analysis of past trends and the exploration of the future evolution of agricultural production in the case study area, at the 2030 time horizon. ${ }^{1}$ Discussions focused on agricultural system dynamics, water being considered only as a factor of production. This sequence aimed at developing temporal awareness. It also helped to reveal the common goals and shared assumptions of the participants, contributed to forging a team spirit, and generated confidence (among the participants, and with the researchers). Water management-related issues were not specifically debated and nothing in the scenarios discussed in this first phase challenged the established water management paradigm.

The second sequence introduced a major uncertainty with the prospect of climate change. The impacts of 
climate change on the hydrological cycle were described in detail, using the results of research conducted in the case study areas. Climate change forecasts introduce an anomaly that challenges the prevailing mindset and forces participants to imagine a different future in terms of farming practices and water management. In this second sequence, we asked the participants to focus on changes that might occur at the farm level (cropping and irrigation practices), while issues related to water resource management in the river basins were postponed to the third sequence.

The third and last sequence was devoted to envisioning possible future groundwater regulation mechanisms, under three alternative models based on (i) strengthened administrative regulation, (ii) market-based regulation, and (iii) self-regulation by the farming community. In this sequence, participants were asked to build on the results of the first two sequences. The objective was to mobilize their analytical and creative capacities and to overcome the limitations imposed by the currently established institutional framework, and also by received values, beliefs and expectations, when thinking about the future. The present paper focuses on this last sequence; the results of the other two are described elsewhere (Maton et al., 2010; Rinaudo et al., In press). The following paragraphs describe how the groups were established and the workshops organized.

\section{Constitution of the group, and workshop organization}

Although the scenario-workshop method usually involves the mixing of policy makers, business representatives, experts and citizens (Street, 1997; Andersen and Jaeger, 1999; Lienert et al., 2006; Hatzilacou et al., 2007), we decided to set up separate groups for various publicinstitutional representatives and experts on the one hand, and farmers on the other. We also opted for smaller groups (5-15 persons) in contrast to the scenario groups described in the literature, where each workshop comprises between 25 and 40 persons (Andersen and Jaeger, 1999; Hatzilacou et al., 2007; Patel et al., 2007). This methodological choice was adopted to overcome the mistrust which characterizes relationships between farmers and public-sector experts.

To facilitate the debates, three contrasting, predefined future water management scenarios were used as material to initiate the debates. Scenario narratives were written by researchers in advance of the workshops, because we assumed that we would not have sufficient time to make trend-breaking scenarios emerge during the 4-5 h scenario workshops. Each scenario consisted of a narrative describing groundwater management rules in 2030-2040 (see the next section for a detailed presentation of the scenarios). The narratives used in Portugal and France were consistent, although adapted to the specific regional contexts. The three scenarios were clearly identified as starting points for discussion, which participants should deconstruct, criticize and adapt according to their views. The workshops were tape-recorded to allow detailed analysis of the views expressed by participants.

In France, discussions of the scenarios took place during workshops held over a half-day period in the evening (6-11 pm), including a meal for the farmers. The workshops were organized as follows. After a brief presentation of the workshop's objectives, the groundwater management scenarios were successively presented, using posters as support. After each presentation, the participants were invited to comment individually during a round-table session before discussing any conflicting points of view. After all the scenarios had been discussed, the participants were invited to prepare individual rankings of the three scenarios according to their probability and desirability. Comparison of these pictures of the probable and desirable futures gave rise to a final group discussion.

A similar approach was implemented in the Portuguese case study. Prior to debating the scenarios, the research team presented the current administrative framework of water management. Then a reference scenario was presented, followed by three separate presentations of the alternative groundwater regulation scenarios, and each was discussed first in small groups and then in a round-table format. The issues of probability and desirability for each of these three scenarios were also discussed. Whereas the farmers were invited to a workshop, the experts and institutional stakeholders were met individually in face-to-face interviews. In both case studies, a final meeting was then organized with farmers and institutional stakeholders together.

A key feature of our approach is that, since the workshops were organized in a research context, the aim was to encourage the expression of various pictures of the future, and to facilitate the mutual discovery of differing points of view concerning the future development of agriculture, and the associated irrigation water demand and water management frameworks. The posture adopted by the team was thus exploratory and not normative.

The key features of the two case studies are presented in Table I and in subsequent sections.

\section{French case studies}

In France, the Roussillon groundwater basin was selected for implementing the methodology described above. 
Table I. Main features of the two case study areas

\begin{tabular}{|c|c|c|}
\hline & Roussillon (France) $)^{\mathrm{a}}$ & Querença-Silves (Portugal) ${ }^{\mathrm{b}}$ \\
\hline \multirow[t]{3}{*}{$\begin{array}{l}\text { Geography } \\
\text { and climate }\end{array}$} & Coastal plain $\left(700 \mathrm{~km}^{2}\right)$ & $\begin{array}{l}\text { Most important groundwater reservoir in the Portuguese Algarve } \\
\text { region }\left(317.85 \mathrm{~km}^{2}\right)\end{array}$ \\
\hline & Rainfall $=570 \mathrm{~mm} \mathrm{yr}^{-1}$ & Rainfall $=653 \mathrm{~mm} \mathrm{yr}^{-1}$ \\
\hline & Mediterranean climate & Mediterranean climate \\
\hline \multirow[t]{3}{*}{$\begin{array}{l}\text { Water } \\
\text { resources }\end{array}$} & $\begin{array}{l}\text { Two coastal aquifers: (a) Pliocene } \\
\text { confined aquifer (abstraction }=41 \mathrm{Mm}^{3} \mathrm{yr}^{-1}\end{array}$ & $\begin{array}{l}\text { Aquifer built of karstified limestones and dolomites. Total } \\
\text { abstraction }=21.441 \mathrm{Mm}^{3} \mathrm{yr}^{-1}\end{array}$ \\
\hline & $\begin{array}{l}\text { and (b) Quaternary shallow alluvial aquifer } \\
\left(\text { abstraction }=43 \mathrm{Mm}^{3} \mathrm{yr}^{-1} \text { ) }\right.\end{array}$ & $\begin{array}{l}\text { Large reservoirs supplying water to public water utilities } \\
\text { (drinking water use) }\end{array}$ \\
\hline & $\begin{array}{l}\text { Large reservoirs supply water to gravity } \\
\text { irrigation canals (agriculture) }\end{array}$ & $\begin{array}{l}\text { Multi-municipal public water supply system managed by the } \\
\text { regional water utility, Águas do Algarve }\end{array}$ \\
\hline \multirow[t]{3}{*}{$\begin{array}{l}\text { Groundwater } \\
\text { uses }\end{array}$} & Drinking water $\left(52 \mathrm{Mm}^{3} \mathrm{yr}^{-1}\right)$ including tourism & $\begin{array}{l}\text { Agriculture: } 6816 \text { irrigated ha (from a total area of } 32000 \mathrm{ha} \text { ), } \\
1784 \text { wells, } 30 \mathrm{hm}^{3} \mathrm{yr}^{-1} \text { (average) }\end{array}$ \\
\hline & $\begin{array}{l}\text { Agriculture: } 15000 \text { irrigated ha, } 4500 \\
\text { boreholes, abstraction of } 23 \mathrm{Mm}^{3} \mathrm{yr}^{-1}\end{array}$ & Drinking water: $10 \mathrm{hm}^{3} \mathrm{yr}^{-1}$ \\
\hline & Industry $\left(4 \mathrm{Mm}^{3} \mathrm{yr}^{-1}\right)$ & $\begin{array}{l}\text { Several data coexist and detailed data are still being constructed } \\
\text { by ARHA and experts of the University of Algarve }\end{array}$ \\
\hline $\begin{array}{l}\text { Threats to } \\
\text { groundwater }\end{array}$ & $\begin{array}{l}\text { Risk of seawater intrusion } \\
\text { (locally observed). Declining } \\
\text { groundwater table in confined aquifer }\end{array}$ & $\begin{array}{l}\text { Risk of brackish water intrusion from the estuary into the karst } \\
\text { aquifer }\end{array}$ \\
\hline
\end{tabular}

${ }^{a}$ Source: Montginoul and Rinaudo (2009).

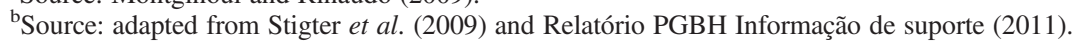

Located in southern France, and covering an area of 700 $\mathrm{km}^{2}$, the Roussillon is characterized by one of the driest climates in France (average precipitation of $570 \mathrm{~mm}$ ). The presence of relatively abundant surface and underground water resources has enabled the development of irrigation farming (about 15000 ha irrigated), which produces mainly vegetables (tomatoes, cucumbers, potatoes and artichokes) and fruit (peaches, nectarines and apricots). About 11000 ha are irrigated by open gravity channels which draw their water from three rivers, two of which are controlled by dams. The remainder of the irrigated area relies on an estimated 4500 individual boreholes, only a few dozen of them being officially registered and equipped with the metering devices required by law.

Over the last decade, groundwater management matters have become particularly fraught, for a number of reasons. First, the doubling of the population between 1954 and 2007, and the development of tourism along the coast, have created a substantial increase in drinking water demands. These needs have been met by increasing withdrawals of groundwater, leading to a lowering of the water tables and temporary restrictions on the use of boreholes, especially for agriculture during periods of drought. Long-term predictions of climate change suggest that tensions over water resources are likely to become only more severe. According to the work of the Vulcain Project, irrigation water needs will increase (Rinaudo et al., In press) and river flows are expected to fall by about $20-40 \%$ by 2030 (Caballero et al., Submitted), resulting in increased pressure on groundwater resources.

This evolution is taking place in a context of changing groundwater governance. Historically, access to groundwater use has been loosely regulated in France, which has resulted in a widespread perception that groundwater is an open-access good (Barraque, 2004). This situation is currently changing, with the progressive implementation the Water Framework Directive and the subsequent 2006 Water Law. This law requires that a maximum permissible annual volume (MPAV) be defined for each aquifer at risk of overexploitation, and that pumping authorizations be allocated in light of this constraint. Although the law and its implementing regulations do not specify how this overall quota has to be shared among users, it certainly represents a first step towards a more regulated water allocation mechanism. In this context, local stakeholders and government agencies have recently initiated a groundwater management plan for the Roussillon aquifers. Hydrogeological studies are currently being conducted to determine the MPAV that can be pumped from the aquifer. Stakeholders and government agencies are also beginning to discuss arrangements that could be put in place to share the MPAV among farmers. This discussion is taking place in a very unfavourable economic situation for agriculture (a succession of several bad economic and climatic years). 


\section{Portuguese case study}

Located in the south of Portugal, in the heart of the Algarve region, the $318 \mathrm{~km}^{2}$ Querença-Silves aquifer is the largest and the most important in the region. The main water uses are for farming and drinking, with more limited use by golf courses and industries. This aquifer is located in one of the most popular seaside tourist areas of Portugal, in which there is a tenfold population increase during the summer months. Farmers grow mainly citrus fruit, and overall their farms face marketing difficulties. In the summer of 2005 , the extreme drought Portugal was going through brought this aquifer down to record low levels, and pumping was restricted because of fears of saltwater intrusion. While there is as yet no evidence of groundwater overdraft, the Regional Water Administration of the Algarve is keen to ensure that it does not occur in the future. In a 2009 report, the administration considered the Querença-Silves aquifer to be at risk of overexploitation, with water extraction exceeding 90\% of the recharge (ARHA, 2009).Moreover, recent research has produced simulations showing that climate change could exacerbate the problem, resulting in seawater intrusion (Stigter et al., 2009).

In Portugal as in France, groundwater is privately owned, while most surface water has been placed in the public domain. However, overexploitation reported in the south has led to changes. In 1966, a new civil code gave government the ability to subject groundwater use to regulations, but this was not enforced until 1977, when a decree law (No. 376/77) created a licensing system for water abstraction in the southern areas where aquifers are the only significant resources. The licensing system was expanded to cover the whole country in 1995 , with varying levels of restrictions. Thus the trend is towards greater administrative control of private water rights, rather than towards redefinition of groundwater as a common property subject to user rights, which would lead to user boards like those proposed in Spain (Barraque, 2004).

The Portuguese case study was carried out while the newly established Regional Water Administration of the Algarve (RWAA) was developing its regional water management plan, in compliance with the Water Framework Directive. A specific groundwater management plan was not planned at the time. The RWAA is the agency that issues licences for the use of water and determines the maximum permissible volume that can be pumped per borehole. These regulations work well on paper but not in practice. Even though the RWAA has a geographic information system that supports the issuing of groundwater licences, there are still a significant number of unregistered boreholes (ARHA, 2009). Furthermore, many water users do not have metering devices or do not use them, in spite of an obligation to send this information to the administration. All of these are considered serious or very serious infractions, which can incur penalties ranging from $€ 25000$ to $€ 2500000$ (the maximum penalty for not registering the borehole). Since control by the administration is very weak, the farmers are not concerned about complying (as they say: 'no one does it'). A recent campaign of compulsory well registration was implemented in an effort to change this state of affairs, but its results are not yet known (currently there are 19626 declared wells in the Algarve region). Farmers harshly criticize the current system of water use regulation, as they find it ignores their needs; for example, the volumes authorized are considered to be insufficient in the summer months. Another issue worrying farmers is the establishment (in 2009) of a new tax on water abstraction. Although the tax level is very low, farmers see it as a first step towards the enforcement of groundwater payments, something they deem unfair considering the already high electricity costs and their significant investments in well construction.

\section{GROUNDWATER REGULATION SCENARIOS}

In both France and Portugal, groundwater policy is currently at a crossroads where three different models may be chosen to develop national groundwater regulation policies. The first model consists of developing direct administrative regulation, with systematic registration of abstraction points, the issuance of permits, the definition of groundwater rights, and the awarding of concessions. The second model consists of relying on economic instruments, such as water pricing or tradable water licences, to regulate the use and allocation of groundwater. The third model is self-regulation, consisting of establishing semiautonomous groundwater users' associations (GWUAs) with the internal capacity of organizing groundwater regulations, supported by higher-level authorities (LopezGunn and Cortina, 2006). Three narrative storylines were developed to introduce and arouse debate on these three models with institutional representatives, experts and farmers. These storylines are briefly presented below.

\section{Scenario A: the regulatory approach}

This scenario assumes that groundwater becomes entirely regulated by the state. Drawing on approaches implemented in Spain with the regimen de explotacion (Lopez-Gunn, 2003) and in some groundwater basins in western states of the USA (Schlager, 2006), this scenario assumes that a government agency registers all groundwater abstraction points, issues permits, defines groundwater rights (volume per year), and awards concessions. It further assumes that farmers provide detailed information 
(at the plot level) on where they use water and for which crop, in a framework similar to what is currently done in order to obtain Common Agriculture Policy subsidies. The government agency then checks that the declared irrigated areas and cropping patterns are consistent with the authorized water use. The enforcement problem is dealt with by the use of sophisticated remote-sensing technology coupled to a geographic information system. Satellite images are regularly acquired and analysed to identify and map all irrigated areas. The volumes used in each field are estimated using the same images. This information is integrated into a numerical land registry in order to compare actual water use with legal water entitlement. In the event of inconsistency between declared and estimated water use, a field inspection is carried out. Severe sanctions apply in cases of noncompliance, the sanction consisting of a fine proportional to the excess water used. One of the problems associated with this scenario is the lack of flexibility: newcomers (young farmers) are unable to obtain a concession until another farmer relinquishes a licence-possibly providing incentives for farmers to drill illegal wells or to engage in informal water trading.

\section{Scenario B: tradable water permits}

The second scenario retains all the assumptions of the regulatory scenario and further assumes that water concessions can be traded among farmers. Both shortand long-term exchanges can take place. Transactions are approved and registered by a regulatory authority which checks that the transaction has no third-party impact. Details of all transactions are published by the regulatory authority (price and volumes exchanged) to ensure transparency. Specific measures are implemented to prevent speculation, mainly consisting of recalling dormant licences from farmers who have not directly used them for several consecutive years. The main questions raised by this scenario are related to the functioning of water markets (type of farms likely to actively engage in trading, type of exchanges that would take place, namely short- or long-term sales), and to the social acceptability of considering trading water concessions in a legal framework in which water is considered to be a common good (France), and the risks of market failure in both the French and Portuguese contexts.

\section{Scenario C: self-regulation}

The third scenario is inspired by various examples around the world where water users have successfully organized themselves into associations to safeguard groundwater resources (Lopez-Gunn, 2003; Lopez-Gunn and Cortina, 2006; van Steenbergen, 2006; Schlager, 2007) and to prevent the tragedy of the commons from happening. The example of the groundwater user association (GWUA) established in Eastern Mancha (Junta General de Regantes de la Mancha Oriental) was specifically studied when constructing this scenario (Calera Belmonte et al., 1999; Lopez-Gunn, 2003; Martín de Santa Olalla et al., 2003).

This scenario assumes that GWUAs are established and made responsible for the allocation of the (MPAV) among farmers. The GWUA develops the internal capacity to register boreholes and monitor the volumes of water used by its members, without state interference. Membership in a GWUA is mandatory for any farmer wishing to exploit groundwater (the state ensures compliance with this). The GWUA, which is responsible for enforcing the overall quota (MPAV), controls the individual behaviour of its members. A groundwater tribunal, composed of elected farmers, is established to arbitrate on conflicts, and to impose penalties on offending farmers (illegal wells or overpumping). Government agencies are asked to intervene only if the tribunal's order is not carried out. The main questions raised by this scenario are related to the assumption that a GWUA can effectively monitor groundwater access and use by its members, and to the assumption that self-adjudication and enforcement of sanctions can work.

\section{RESULTS: WHAT DID WE LEARN FROM THE SCENARIO WORKSHOPS FOR POLICY FORMULATION?}

\section{Lessons learnt concerning the definition and enforcement of individual water rights}

The regulatory scenario is perceived as a rigid and authoritative solution that may escalate the conflicts between authorities and water users. In both case studies, farmers and stakeholders stressed that a major constraint that limits the scope for this scenario is that there is insufficient shared knowledge of the aquifer boundaries, the volume that can be extracted, and the risks of deterioration. Owing to this lack of scientifically sound information, water rights defined by the state are likely to be contested. In the Roussillon, this problem had already been identified in interviews conducted several years ago (Montginoul and Rinaudo, 2009). Surprisingly, farmers are not opposed to strict water-use monitoring carried out via a combination of meters and the use of remotesensing imagery. In France, farmers consider this as being an unavoidable development in the short term (five years) which is totally consistent with the practices of government agencies responsible for implementing 
the European Common Agricultural Policy. No conflict is expected concerning the use of remote sensing as a monitoring tool, in contrast with what Lopez-Gun (2003) reports from Western Mancha. Portuguese farmers would also accept stricter monitoring systems in a context of scarcity but they want to be better informed about such a system and also require greater transparency and equity in its implementation (mix of scenarios $\mathrm{A}$ and C). The necessity of penalties is not contested; however, in the case of overpumping, French farmers suggest replacing financial sanctions by a reduction of the quota authorized for the following year (as is already happening in the Vendée region in western France for instance, and in the Eastern Mancha aquifer in Spain). For Portuguese farmers also, penalties are not contested, but it is definitely a sensitive topic. For farmers, penalties should be avoided given the difficult economic situation of agriculture, but the state could instead withhold all public subsidies (CAP in particular) from offending farmers. Penalties for infraction should be the very last resort.

\section{Lessons learnt concerning trading of rights}

Overall, French and Portuguese farmers all express major concerns relating to the ethical implications of establishing a market for water rights. They firmly oppose considering water as a commodity that can be traded. As one farmer puts it, 'we can sell everything but not water'. Also, they are particularly concerned about the assumed separation of land and water property, fearing that this would lead to the concentration of water rights in the hands of a few better-off farmers, resulting in the abandonment of large tracts of land. As far as small farmers (who refer to themselves as 'peasants') are concerned, the scenario somehow threatens their existence, whereas it opens up new prospects for large farmers (who were not well represented in our groups).

After having made clear that this scenario was not a desirable outcome, the French farmers, who agreed to discuss this scenario in detail, acknowledged that it was not totally improbable. To support this judgement, they spontaneously quoted the existence of similar cap and trade mechanisms used for the regulation of greenhouse gas emissions. They also mentioned that similar markets already exist in agriculture for regulating the allocation of certain production rights, e.g. vine plantation rights, milk quotas, shellfish concessions. Finally, they agreed that tradable water rights should be considered and debated, given that these could appear on the policy makers' agenda in the future.

From that point in the discussion, some of the workshop participants clearly shifted to an exploratory mode, making an effort to envisage how the mechanism would work. They identified a number of situations where trade could offer flexibility (for instance during the first 4-5 yr of orchard plantation farmers could lease their water rights since they would not fully use them). They agreed that trade could be beneficial to farmers in specific situations. Trade would most probably remain limited and consist of long-term (or definitive) transfers (sale of water rights after retirement), although short-term transactions (from a few weeks to 1-2 yr) might also take place at the margin. Participants were quite imaginative in identifying potential problems and drawbacks, including prohibitive transaction costs and third-party effects generated by the concentration of water rights in specific geographic areas. Tradable water rights were also expected to increase the complexity of land markets and to increase the resources needed by young farmers entering the sector (purchase of water rights in addition to land, machinery, etc.). A clear risk of speculation was pointed out, assuming that some farmers (market gardeners) might purchase water rights, use them during wet years, and speculate during drought years. Last but not least, farmers were concerned that water rights could be transferred to cities, for instance by farmers retiring, resulting in the progressive disappearance of agriculture. In conclusion, some of the farmers agreed that a system of tradable water permits could be established, provided that water permits would remain linked to the land and exchanges were limited to short-term leases of permits.

\section{Lessons learnt concerning self-regulation}

In the two case studies, farmers clearly expressed the desire to be more closely involved in decisions defining groundwater regulation rules. However, some differences emerged between the French and Portuguese farmers.

In Portugal, farmers did not believe that groundwater users' associations could take over responsibility for groundwater regulation, citing the lack of trust among them. Bonding social capital seems to be fairly weak within the community, given past experiences of failed collective action in associations and cooperatives, whose leaders are often accused of favouring some associates and even of corruption. For these farmers, collective action for self-regulation of the aquifer was viewed as possible only in a critical situation, such as a serious lack of water or in reaction to a more threatening alternative that might be imposed by the state, such as a higher water abstraction tax, for instance. The groundwater tribunal was also criticized. It should not be made up of farmers only but should rather include a wide range of representatives, including some external to agriculture, 
to ensure its independence and impartiality. It should also be led by a professional judge, not by a farmer. They nonetheless pointed out some advantages of selfregulation such as the greater proximity to local reality of those managing the aquifer, which they contrast with the 'state's technocrats', and their greater participation in decisions that are important to them, e.g. the rules for allocating quotas. They emphasize that these associations need to be a bottom-up creation, as associations created by the state are doomed to fail. As for the representatives of government agencies, they are very dubious about the capacity of farmers to get organized and to devise and implement groundwater-governing institutions, although they are in favour of such a system, within a wider governance framework defined by the state. One representative went so far as to say that the state should test self-regulation in a site such as that of the Querença-Silves aquifer.

In the French case study, workshop participants were much more supportive of the self-regulation principle. This is probably due to the positive experience with the irrigation associations which have been successfully managing gravity-irrigation canals. Representatives from government agencies adopted a very positive attitude, agreeing with the idea of giving up part of their powers and recognizing the right of users to devise their own institutions. Farmers also supported the scenario, although they were fully aware that a large number of the social problems arising from diverging interests and the effective implementation of the rules would shift from the authorities to the farmers' organization. Beyond their general support, farmers expressed a number of concerns about the implementation of the proposed scenario. First, they said that it was unlikely to become reality until a serious crisis occurred, triggering collective action. 'Crisis' was understood as a situation where agriculture would be designated as responsible for (or even the culprit in) the emerging water crisis, forcing farmers to engage in collective action to defend their interests; or a situation where water shortage might reach such an intensity that sharing water would become a issue of survival, forcing farmers to act collectively.

French farmers also pointed out that the scenario breached the fundamental principle of separation of powers, as the farming community itself would be in charge of formulating the regulating rules, interpreting those rules, adjudicating conflicts and implementing penalties. They called for the state to remain involved in the adjudication and enforcement of sanctions, suggesting that the tribunal could, for instance, be composed of state representatives and farmers in equal proportions. This position was reinforced by the relative lack of trust, reflecting fears that a group of farmers would highjack the collective organization for their personal benefit, by influencing the decisions of the tribunal or the enforcement of sanctions. They also believe that selfmonitoring is unlikely to be effective, since 'neighbours do not denounce neighbours'. Last but not least, the farmers claimed that the supporting role of public authorities in the establishment of a self-regulating institution was inadequately defined in the scenario, GWUAs being perceived as operating in a vacuum. Overall, the farmers were somewhat uncomfortable with this scenario as they felt that it was driven by the state's desire to shed the burden of managing a common good. This supported the conclusions of previous research work which emphasized the role of higher authorities in effective selfregulation arrangements (Schlager and Lopez-Gunn, 2008; Lopez-Gunn and Cortina, 2006).

\section{DISCUSSION AND CONCLUSION}

\section{Summary of participants' perceptions of scenarios}

When asked to describe how water management is likely to evolve in the future, French stakeholders and farmers quoted most of the items contained in the self-regulation scenario (C). They do not believe that the state will intervene in water management as described in regulatory scenario (A), and most of them consider the development of the water markets scenario to be very unlikely (B). Overall, Scenario $\mathrm{C}$ is considered to be highly desirable by more than $90 \%$ of the participants. However $30-40 \%$ of participants also find that some of the assumptions included in Scenarios A and B should be considered, and included in a hybrid scenario.

For Portuguese stakeholders, the state should continue to play a crucial role in the management of groundwater. Although they call for greater involvement of farmers in groundwater regulation, the participants did not support the self-regulation scenario. The water market scenario is categorically dismissed by most participants, who consider it unethical.

In short, the outcome of the participatory foresight conducted in the two countries has enabled the identification of certain key elements which could be taken from the various scenarios and combined to formulate a preliminary basis for discussion with stakeholders. In Portugal, this scenario would be based on the regulatory scenario, farmers being granted a much greater participation in the definition of the rules of use, monitoring and sanctions. In France, the self-regulation scenario could serve as a basis for discussion, provided the role of the state is clarified (and partly reinforced as regards the 
adjudication and enforcement of penalties). The workshops also identified one form of trading which might be considered as acceptable (in France) provided land and water property rights remain linked. Overall, the debates highlighted the need to create an institutional culture in which groundwater users are perceived as potential co-managers, not just as users safeguarding their own private individual uses, as already stressed in other contexts (Agarwal, 2001).

From a methodological point of view, the research presented above has demonstrated farmers' ability to contribute to an exploratory assessment of possible future water-management scenarios, in two contexts where water is not an immediate source of concern for agriculture but only an anticipated future challenge. Significant positive changes in attitudes took place during the participatory process, with farmers opening up to a diversity of possible futures. In France, for instance, some of the farmers who were initially unwilling to consider basic changes, such as the installation of meters and the allocation of individual quotas, have been able to discuss, evaluate, and provide very meaningful comments and suggestions on highly innovative water-management scenarios, e.g. water markets. However, this does not mean that they would accept implementation of the scenarios, but they were at least able to discuss them.

Farmers, experts and institutional representatives alike appreciated the opportunity for debate offered by the scenario workshops. Overall, all of the participants said that they found the discussion time valuable. The workshops offered them a unique opportunity to think about the consequences of long-term changes, something which neither farmers nor institutional experts have time to do, being trapped within their present constraints and short-term objectives. Another key motivation for participants was the opportunity offered by the workshop to listen to each other's opinions, in a strategic, behaviourfree context, i.e. having the possibility to freely express all their ideas without concern for the defence of specific vested interests. This was emphasized by the institutional experts, who are used to meeting in arenas where they have to defend vested interests and entrenched positions dependent on their institutions, with regard to short-term political and economic issues (Rinaudo et al., In press). Portuguese farmers also appreciated learning from scientists, in particular on issues related to the dynamics of the aquifer, climate change and its effects on cultures, and water-management institutions. The choice of a methodology that consisted in conducting a series of participatory foresight workshops has generated substantial social learning. It is, however, unclear if this process will be continued by authorities or farmers themselves after the research project ends.
Concerning the use of predefined scenarios, participants found the three scenarios useful as a basis for discussion, recognizing that exploring possible futures would have been very difficult if not impossible without such support. However, some participants regretted that scenarios were presented as static descriptions of three different possible future situations, without considering possible transition paths from the present to the futures considered. Naturally, this methodology is not flawless, and other types of foresight techniques could be used, explicitly considering transition paths in the scenario description (Poumadère et al., 2008) or using facilitating tools such as role-playing games or experimental economics. This type of alternative approach has already been used in another case study conducted in Morocco (ref. to Faysse, this issue), and is currently being tested by the French research team, as an extension of the work presented in this paper (Lenouvel et al., 2011).

\section{ACKNOWLEDGEMENTS}

The results presented here were produced as part of AQUIMED, a research project contributing to the ERA Net CIRCLE programme. Financial support from Fundação para a Ciência e Tecnologia (Portugal) and the Ministry of Ecology (France) is acknowledged. The research related to water markets presented in this paper has also benefited from financial support from ONEMA (France) as part of the Water Cap \& Trade project, funded under the Era Net IWRM Net programme. We wish to acknowledge the very useful comments and suggestions of three anonymous reviewers of this paper.

\section{ENDNOTES}

1. The analyses of past trends and of the current situation were carried out through interviews in France and through interviews and a preliminary workshop in Portugal. The exploration of the future development of agriculture was undertaken in a specific workshop during the two case studies.

\section{CONFLICT OF INTEREST}

The authors have no conflicts of interest to declare.

\section{REFERENCES}

Agarwal B. 2001. Participatory exclusions, community forestry, and gender: an analysis for south asia and a conceptual framework. World Development 29(10): 1623-1648. 
Andersen I-E, Jaeger B. 1999. Scenario workshops and consensus conferences: towards more democratic decision-making. Science and Public Policy 26: 331-340.

ARHA. 2009. Questões significativas da gestão da água, Região Hidrográfica das Ribeiras do Algarve, Participação pública, Informação de Suporte, January.

ARHA. 2011. Plano de Gestão de Bacias Hidrográficas que integram a Região Hidrográfica das Ribeiras do Algarve. Paper presented at the Forúm de Participação Pública. Informação de Suporte, May.

Barraque B. 2004. Groundwater management in France: from private to common property? In Brentwood M, Robar S (eds). Managing Common Pool Groundwater Resources: an International Perspective, Praeger: Westport, CT.

Caballero Y, Maton L, Terrasson I, Fleury P, Dorfliger N, Ladouche B, Chazot S, Rinaudo J-D, Neppel L, Martin E, Salas y Melia D, Pinault J-L. Submitted. Vulnerability of mediterranean hydrosystems to global change: an assessment method. Global and Planetary Change.

Calera Belmonte A, Medrano Gonzalez J, Vela Mayorga A, Castana FS. 1999. GIS tools applied to the sustainable management of water resources: application to the aquifer system 08-29. Agricultural Water Management 40(2-3): 207-220.

European Academies Science Advisory Council (EASAC). 2010. Groundwater in the Southern Member States of the European Union, Postfach, Germany.

García-Ruiz JM, López-Moreno JI, Vicente-Serrano SM, Lasanta-Martínez T, Beguería S. 2011. Mediterranean water resources in a global change scenario. Earth-Science Reviews 105: 121-139.

Godet M, Roubelat F. 1996. Creating the future: the use and misuse of scenarios. Long Range Planning 29(2): 164-171.

Hatzilacou D, Kallis G, Mexa A, Coccosis H, Svoronou E. 2007. Scenario workshops: a useful for participatory water resources planning? Water Resources Research 43. DOI: 10.1029/2006WR004878.

van der Helm R. 2003. Challenging futures studies to enhance EU's participatory river basin management. Physics and Chemistry of the Earth, Parts A/B/C 28: 563-570.

Lenouvel V, Montginoul M, Thoyer S. 2011. From a blind truncheon to a one-eyed stick: testing in the lab an optional target-based mechanism adapted to groundwater withdrawal. In Conference of the European Association of Environmental and Resource Economists, Rome, Italy; 23 pp.

Lienert J, Monstadt J, Truffer B. 2006. Future Scenarios for a sustainable water sector: a case study from Switzerland. Environmental Science and Technology 40(2): 436-442.

Llamas R, Garrido A. 2007. Lessons from intensive groundwater use in Spain: economic and social benefits and conflicts. In Giordano M, Villholt KG (eds). The Agricultral Groundwater Revolution: Opportunities and Threat to Development, CAB International: Oxford.
Lopez-Gunn E. 2003. The role of collective action in water governance: a comparative study of groundwater user associations in La Mancha Aquifer in Spain. Water International 28(3): 367-378.

Lopez-Gunn E, Cortina L. 2006. Is self-regulation a myth? Case study on Spanish groundwater user associations and the role of higher-level authorities. Hydrogeology Journal 14(3): 361-375.

Martín de Santa Olalla F, Calera A, Domínguez A. 2003. Monitoring irrigation water use by combining Irrigation Advisory Service, and remotely sensed data with a geographic information system. Agricultural Water Management 61: 111-124.

Maton L, Rinaudo J-D, Caballero Y, Richard-Ferroudji A, Rollin D, Garin P. 2010. Que pensent les agriculteurs et les acteurs institutionnels des impacts du changement climatique sur l'agriculture des Pyrénées Orientales et des adaptations possibles? Résultats d'une démarche participative. In Agir en situation d'incertitude. Agropolis International: Montpellier.

Montginoul M, Rinaudo J. 2009. Quels instruments pour gérer les prélèvements en eau souterraine? Le cas du Roussillon. Economie Rurale 310: 40-56.

Ostrom E. 1990. Governing the Commons: the Evolution of Institutions for Collective Action. Cambridge University Press: Cambridge.

Patel M, Kok K, Rothman DS. 2007. Participatory scenario construction in land use analysis: An insight into the experiences created by stakeholder involvement in the Northern Mediterranean. Land Use Policy 24(3): 546-561.

Poumadère M, Mays C, Pfeifle G, Vafeidis A. 2008. Worst case scenario as stakeholder decision support: a 5- to 6-m sea level rise in the Rhone delta, France. Climatic Change 91(1-2): 123-143.

Rinaudo J-D, Maton L, Terrasson I, Chazot S, Richard-Ferroudji A, Caballero Y. In press. Combining scenario workshops with modeling to assess future irrigation water demand. Agricultural Water Management.

Rinaudo JD, Garin P. 2005. The benefits of combining lay and expert input for water-management planning at the watershed level. Water Policy 7(3): 279.

Schlager E. 2006. Challenges of governing groundwater in U.S. western states. Hydrogeology Journal 14(3): 350-360.

Schlager E. 2007. Community management of groundwater. In Giordano M, Villholt KG (eds). The Agricultral Groundwater Revolution: Opportunities and Threat to Development, CAB International: Oxford.

Schlager E, Lopez-Gunn E. 2008. Collective systems for water management: is the Tragedy of the Commons a myth? In Llamas MR, Rogers P (eds). Water Crisis: Myth or Reality? Balkema Publishers: Amsterdam, The Netherlands; 43-58.

Stigter TY, Monteiro JP, Nunes LP, Vieira, CMC, Ribeiro L, Nascimento J, Lucas H. 2009. Screening of sustainable groundwater sources for integration into a regional drought-prone water supply system. Hydrology and Earth Systems Sciences 13: 1185-1199.

Street P. 1997. Scenario workshops: a participatory approach to sustainable urban living? Futures 29(2): 139-158.

van Steenbergen F. 2006. Promoting local management in groundwater. Hydrogeology Journal 14: 380-391. 